\title{
A Review of Psychodrama and Group Process
}

\author{
Yehoshua $^{1}$, Siu Fung Chung, ${ }^{1,2, *}$ \\ ${ }^{1}$ School of Health, The University of New England, Australia, Armidale, NSW, Australia \\ ${ }^{2}$ Kiang Wu Nursing College of Macau, Macau SAR, PR China \\ *Corresponding Author: sfchung@kwmc.edu.mo
}

\begin{abstract}
In recent years, group work therapy has been expanded rapidly throughout the world in helping professionals. Psychodrama, as a form of group psychotherapy, has already shown the potential for bringing about positive change in participants for almost 80 years. However, while psychodrama is primarily a form of group psychotherapy, psychodrama practitioners and researchers have seldom recognized it as a group work. Hence, the connection between psychodrama and group process has rarely been addressed. This review examines the development of research in the connection between psychodrama and group process. An extensive literature search including books, reports, monographs and journal articles has been conducted. It is found that before the new century, psychodrama practitioners and researchers have largely ignored the group process. In addition, most research findings were not published in peer-review journals. Encouragingly, in the last ten years, most empirical studies of psychodrama have incorporated group process in their analysis or discussion. Moreover, most of these studies are reported in peer-reviewed journals. However, there is still a lack of research studies which examine the interaction of psychodrama and the group process. It is hoped that the results of this study will stimulate further research in this area and can increase the awareness among psychodrama practitioners, trainers, and researchers of the need to be equally cognizant of both psychodrama processes and group work.
\end{abstract}

Keywords Psychodrama, Group Process, Review

\section{Introduction}

Psychodrama had been developed as a form of psychotherapy for almost 80 years (Blatner, 2007). Psychodrama has shown potential for bringing about positive change in participants and is considered as a valid and effective form of psychotherapy. Both psychodrama practices and researches have been expanded rapidly in the recent decades.

Currently, in recent years, group interventions have been expanded throughout the world in helping professionals
(Nuttman-Shwartz and Kleinberg).

However, while most psychodrama practices are conducted in a group work context, psychodrama practitioners and researchers mainly concentrate on the psycho-therapeutic effects of the enactments of the individuals only. They seldom recognized it as a group work. Hence, the connection between psychodrama and group process have rarely been addressed.

This review examines the development of research in the connection between psychodrama and group process. An extensive literature search including books, reports, monographs and journal articles has been conducted.

\section{Process of Classic Psychodrama suggested by Dayton}

The Warm-up Phase

Prior to this phase, it is necessary to ensure that an adequate level of group cohesion and safety has been achieved. It is the responsibility of the group therapist/psychodrama director to assist the group/individuals to become warmed up to each other and the group as a whole. In this context, warm-up means being mentally and/or emotionally and/or physically ready to carry out the work of the group. Where individual are concerned, it means they are ready to work on a personal issue.

There are three ways to select a protagonist: a group member may put themselves forward; a number of group members may put themselves forward simultaneously and the director will get the group to choose which one it wants to be the protagonist; or, the director will select a protagonist.

Frequently the issue arising in the protagonist is also a current hidden group theme/issue. This means, the drama will not only benefit the protagonist but will also benefit the group as a single entity.

\section{The Action Phase}

After the protagonist is warmed-up, the director will invite him or her to create a scene on the stage. A scene consists of a time, a place, people and objects. Audience members will be chosen by the protagonist to play all the elements in the scene.

The director will use role-reversal to deepen the protagonist's warm-up. This technique involves the 
protagonist reversing roles with all the elements in the scene. This enables the auxiliaries to play the roles better and gives the protagonist a new perspective on the underlying personal issue.

Once all the auxiliaries have learned their roles, the director will chose an auxiliary to take the place of the protagonist on stage. The director will then withdraw the protagonist to a place where they can observe the whole scene and instruct the auxiliaries to take up their roles and play out the scene. This is called mirroring. It enables the protagonist to be an observer of their issue and the scene surrounding it. This technique can have a strong integrative cathartic effect.

Other techniques used to assist the protagonist to increase their warm-up are doubling and soliloquy. In doubling, an audience member is chosen to become the protagonist's alter ego and remain physically close to, and slightly behind, them. They mimic everything the protagonist says and does. The double can also say out loud all the thoughts that they believe the protagonist is repressing. In soliloquy, the director will suggest that the protagonist walk around the stage saying out loud any thoughts that come into their awareness. The physical action of walking can facilitate the expression of thoughts and emotions that can be repressed when being still.

When the director senses that the drama is completed, he or she will say so to the protagonist and, if they agree, the action phase is ended. It is not necessary for an issue to be resolved in a single drama. Many dramas may be required.

\section{The Sharing Phase}

After the stage is cleared, the director and protagonist remain on the stage sitting together facing the audience. This the first step towards returning to being a group. The director invites the other group members to share experiences from their lives that resonate with the drama. This self-disclosure helps bring the protagonist back from their drama, in another place at another time, to the present moment in the group (Dayton, 2005).

\section{Group Psychotherapy}

At a theoretical level, it is believed that in group therapy the major agent for change is the group itself. This is opposed to individual therapy where the therapist is seen as the major change agent (Bakali, Wilberg, Hagtvet, \& Lorentzen, 2010).

\section{Group processes}

In group psychotherapy, group processes are classified as nonspecific factors as opposed to specific factors which are the active interventions of the therapist. When exploring group processes the question is whether group psychotherapy contains unique non-specific factors that make it more effective than individual therapy? If this is true, which factors make it so? (Hornsey, Dwyer \& Tian, 2007)

Hornsey, Dwyer, and Tian (2007) list 12 non-specific therapeutic factors involved in group process: "instillation of hope, altruism, cohesiveness, guidance, identification, interpersonal learning (input), interpersonal learning (output), self- understanding, universality, catharsis, collective recapitalization of the primary family, and existential factors" (p. 568). They point out that all of these factors are held in common with individual therapy except cohesiveness. They also state that there is little theoretical or empirical research into the factors that mediate the connection between group processes and therapeutic outcomes.

Group psychotherapy has suffered from a lack of a universally accepted theoretical framework in regard to group processes and outcome prediction. This has led to researchers having to make their own theories (Hornsey, Dwyer \& Tian, 2007).

\section{Group Development}

Group development researchers assume that there is a common understanding about the meaning of the term group development. In reality, group development is poorly defined and can mean many things. For example, it can mean changes in group cohesiveness, the leader-member relationship, the goals of the members, or task orientation. There are nearly as many theories of group development as they are group development researchers.(Chang, Duck, \& Bordia, 2006).

Kipper and Hundal (2003) list four different approaches to defining group structure: (1) Rutan and Stone, in 1993, described the phases as the formation of the group, the reactive phase, the mature phase, and the determination phase; (2) Yalom, in 1995, described them as: the beginning, the advance group phase and the termination phase; (3) Corey and Corey, in 1997, described them as the initial stage, the transition stage, the working stage, and the ending stage; and, (4) system-centred group therapy, described by Agaraziann in 1997, which classified three phases characterised by authority, intimacy and dependency.

Group development research began in the late 1940s and continued strongly into the 1970s. Most research studied therapy, training and personal development groups. The theoretical models that were constructed saw the progress of a group's development as being linear. In the late 1980s, linear models were disputed following research on task-oriented groups, work groups and problem-solving groups. These groups showed evidence of non-linear development paths. This indicated that a linear model of group development were not universally applicable. Group researchers, therefore, need to consider which type of model applies to the type of group being studied (Chang, Duck, \& Bordia, 2006).

\section{Group Cohesiveness}

Marmarosh, Holtz, \& Schottenbauer (2005) liken group cohesiveness to the therapeutic relationship, between the therapist and client, in individual psychotherapy. They also maintain that, in the literature, the concept of group cohesiveness is varied and more studies are needed to examine how it contributes to changes in group members. 
This view is also supported by Burlingame, McClendon, \& Alonso (2011).

Marmarosh, Holtz, \& Schottenbauer (2005) state that cohesiveness has not yet been consistently or clearly defined. They maintain that it is a multidimensional construct rather than one-dimensional. They also consider that most group factors are an element of cohesiveness.

Burlingame, McClendon, \& Alonso (2011) described the complexity of group structures as follows:

From the perspective of a group member, relationships are comprised of three structural components: member-member, member-group, and member-leader. From the perspective of the therapist, relationships include the same three components as well as two additional: leader-group and, in the case of a co-therapist, leader-leader. The complexity of these multilevel structural definitions coupled with the dynamic interplay among them has created an array of competing cohesion instruments and an absence of a consensual definition.

They see cohesion as having two basic dimensions. Namely, relationship quality and relationship structure.

Relationship quality consists of two factors. The first is acceptance and belonging. The second is work alliances and group climate. Work alliances can be between a member and the group and/or between individual members (Burlingame, McClendon, \& Alonso, 2011).

The structure of cohesion involves relationship function and direction. Vertical cohesion occurs between members and the leader. The horizontal cohesion exists from member to member and from member to the group as a single entity. The function of cohesion involves willingness to cooperate in tasks, and the degree of emotional support felt (Burlingame, McClendon, \& Alonso, 2011).

The structure and quality model of cohesion is an empirically-based definition of group relationships. It effectively addresses the "who", "what", and "how" of group relationships. In spite of this, the research findings linking cohesion to therapeutic outcome remain inconclusive. These correlational studies do not address the question of causality (Burlingame, McClendon, \& Alonso, 2011). Fullagar \& Egleston (2008) found that there was strong evidence that performance predicts cohesiveness rather than the opposite.

Hornsey, Dwyer \& Tian (2007) indicate that there is much disagreement about how to define and measure cohesiveness. They see it as a multidimensional group construct.

Hornsey, Dwyer \& Tian (2007) note that it is difficult to synthesise the group cohesiveness research literature because of the lack of agreement on how to define it.

The group research's fuzzy definitions of cohesiveness has led to a situation where any variable that correlates positively with outcome is deemed to be a measure of cohesiveness (Burlingame, McClendon, \& Alonso, 2011).

Hornsey, Dwyer \& Tian (2007) state that clinical research is blurred about what creates cohesiveness, what are its outcomes, and what are its constituent parts. They imply that researchers have not been able to effectively define this construct. They propose alternative constructs that are unique to group psychotherapy and which, they believe, would be easier to define, namely "identification, homogeneity, interdependence". They also believe that these variables provide a way to establish causality.

\section{Objective}

This review examines the development of research in the connection between psychodrama and group process.

\section{Method}

In order to have the review as comprehensive as possible and gain a more complete understanding of the state of psychodrama research., this study includes secondary and as well as primary sources.

An extensive literature search including books, reports, monographs and journal articles has been conducted. Literature were searched through using keywords search from major academic databases, tracing of reference lists and citing articles in identified articles, and searching of common internet search engines.

\section{Results}

From our analysis of the literature, it is found that before the new century, psychodrama practitioners and researchers have largely ignored the group process. In addition, most research findings were not published in peer-review journals. Some of the comments of important authors are as follows:

Nicholas (2008) comments that psychodrama practitioners and researchers have largely ignored the general field of group psychotherapy. She believes this attitude had its origins in the feud between the founder of psychodrama, J. L. Moreno, and the American Group Therapy Association in the $1950 \mathrm{~s}$.

Treadwell \& Kumar (2002), 10 years ago, lamented that the lack of sufficient scientifically rigorous psychodrama research published in peer-reviewed journals has contributed to its lack of visibility amongst contemporary psychotherapy modalities.

Kipper and Hundal (2003) noted in their meta-analysis of the 34 English language, peer-reviewed quantitative psychodrama studies published from 1970 to 2002, that $66 \%$ were published prior to 1980 . They concluded that, since most psychodrama clinical studies involve single sessions only, this must be the prime mode of treatment. This is in contrast to other forms of group psychotherapy which see the whole group developmental phase structure as being the treatment process. It is as if psychodrama researchers considered the contribution of group process to therapeutic outcomes to be negligible in comparison to that of the psychodrama enactment. They also noted the absence of any 
discussion of group structure, or the stages of group development, from peer-reviewed psychodrama research studies. They were not able to explain this phenomenon.

There are many case studies published in psychodrama association journals and monographs. These, however, do not have the scientific rigour required for publication in peer-reviewed journals. The majority of these studies were published prior to 1980 .

Since then, developments in quantitative research methods have made it possible to achieve the required rigour. Authors of psychodrama case studies, since 1980, have rarely used these methods (Kipper \& Hundal, 2003; McVea, 2004).

A search of English language, peer-reviewed journals revealed 25 psychodrama studies published in the past 10 years (see Table 1). Nine of these acknowledged the influence of group process in a psychodrama group in addition to the influence of classic psychodrama or psychodrama techniques. However, none of these studies explained what they meant by the term 'group process'. Two recommended future studies examine the topic. McVea, Gow, and Lowe (2011) was the only study to include group process impact items in their measurements.

Table 1. Peer-reviewed Psychodrama Studies Acknowledging, Explaining, Examining Group Process Influence

\begin{tabular}{|c|c|c|c|c|c|c|c|c|}
\hline $\begin{array}{l}\text { Author/s } \\
\text { and } \\
\text { Year }\end{array}$ & $\begin{array}{c}\text { PD Approach } \\
\text { or } \\
\text { Technique }\end{array}$ & $\begin{array}{c}\text { Research Question } \\
\text { or } \\
\text { Problem Statement }\end{array}$ & $\begin{array}{c}\text { Research Design } \\
\text { or } \\
\text { Article Type }\end{array}$ & Country & $\begin{array}{c}\text { Group } \\
\text { Process } \\
\text { Mentioned? }\end{array}$ & $\begin{array}{l}\text { Group } \\
\text { Process } \\
\text { Explained? }\end{array}$ & $\begin{array}{l}\text { Group } \\
\text { Process } \\
\text { Examined? }\end{array}$ & $\begin{array}{l}\text { Recommend } \\
\text { Group } \\
\text { Process } \\
\text { Study? }\end{array}$ \\
\hline $\begin{array}{l}\text { Kipper \& } \\
\text { Matumoto, } \\
2002\end{array}$ & $\begin{array}{l}\text { Classic/Analytic } \\
\text { Role-playing }\end{array}$ & $\begin{array}{l}\text { "...explore the hypothesis that } \\
\text { contemporary U.S. psychodramatists } \\
\text { evince a shift from strict adherence } \\
\text { to the conceptual frame of reference } \\
\text { espoused by classical psychodrama } \\
\text { toward a degree of sharing concepts } \\
\text { with those valued by psychodynamic } \\
\text { and interpersonal group } \\
\text { therapists" (p. 112). }\end{array}$ & Qantitative Analysis & USA & No & No & No & No \\
\hline $\begin{array}{l}\text { Hamamci, } \\
2002\end{array}$ & $\begin{array}{l}\text { Classic/CBT } \\
\text { Role-playing } \\
\text { Role-reversal } \\
\text { Doubling } \\
\text { Soliloquy }\end{array}$ & $\begin{array}{l}\text { "...integrated the cognitive behavioral } \\
\text { approach with psychodrama to } \\
\text { evaluate to what extent such an } \\
\text { approach could reduce cognitive } \\
\text { distortions related to interpersonal } \\
\text { relationships" (p. 5). }\end{array}$ & Qantitative Analysis & Turkey & No & No & No & No \\
\hline $\begin{array}{l}\text { Kipper \& } \\
\text { Hundal, } 2003\end{array}$ & $\begin{array}{c}\text { Classic } \\
\text { Role-playing } \\
\text { Role-reversal } \\
\text { Doubling }\end{array}$ & $\begin{array}{l}\text { "In this review, we explored the } \\
\text { characteristics of the practice of } \\
\text { psychodrama as reflected in } \\
\text { published case illustrations and } \\
\text { clinical reports during the period of } \\
1970-2000 . " \text { (p. 143) }\end{array}$ & Literature Review & USA & Yes & No & No & Yes \\
\hline $\begin{array}{l}\text { Kipper \& } \\
\text { Ritchie. } 2003\end{array}$ & $\begin{array}{l}\text { Classic } \\
\text { Role-playing } \\
\text { Role-reversal } \\
\text { Doubling }\end{array}$ & $\begin{array}{l}\text { "Questions concerning the scientific } \\
\text { basis of the clinical application of } \\
\text { psychodramatic techniques have } \\
\text { been raised primarily because of the } \\
\text { infrequency of research publications } \\
\text { that validate the clinical observations. } \\
\text { A meta-analysis conducted on the } \\
\text { basis of } 25 \text { experimentally designed } \\
\text { studies..." (p. 13). }\end{array}$ & Meta Analysis & USA & No & No & No & No \\
\hline
\end{tabular}


Vol.1. No.2 December, 2013, pp. 105-114

\begin{tabular}{|c|c|c|c|c|c|c|c|c|}
\hline $\begin{array}{l}\text { Author/s } \\
\text { and } \\
\text { Yoar }\end{array}$ & $\begin{array}{l}\text { PD Approach } \\
\text { or } \\
\text { Technique }\end{array}$ & $\begin{array}{c}\text { Research Question } \\
\text { or } \\
\text { Problem Statoment }\end{array}$ & $\begin{array}{c}\text { Research Design } \\
\text { or } \\
\text { Articlo Typo }\end{array}$ & Country & $\begin{array}{c}\text { Group } \\
\text { Process } \\
\text { Mentioned? }\end{array}$ & $\begin{array}{l}\text { Group } \\
\text { Process } \\
\text { Explained? }\end{array}$ & $\begin{array}{l}\text { Group } \\
\text { Process } \\
\text { Examined? }\end{array}$ & $\begin{array}{l}\text { Recommend } \\
\text { Group } \\
\text { Process } \\
\text { Study? }\end{array}$ \\
\hline Kim, 2003 & Classic & $\begin{array}{l}\text { "1. Are there significant differences in } \\
\text { therapeutic factors and emotional } \\
\text { changes between the protagonists } \\
\text { and the audience? } \\
\text { 2. As the sessions continue, do the } \\
\text { treatment factors become different } \\
\text { and do participants show emotional } \\
\text { changes? } \\
\text { 3. How do protagonists and the other } \\
\text { group members evaluate the } \\
\text { sessions differently? } \\
\text { 4. How do participants evaluate the } \\
\text { sessions? (P. 117). }\end{array}$ & Qantitative Analysis & Korea & No & No & No & No \\
\hline Jefferies, 2005 & $\begin{array}{l}\text { Classic } \\
\text { Role-playing } \\
\text { Role-reversal } \\
\text { Surplus Reality }\end{array}$ & $\begin{array}{l}\text { "The debate on what can be } \\
\text { effectively done to reduce crime, } \\
\text { protect members of the public and } \\
\text { lower recidivist rates continues in } \\
\text { many quarters. As a result there are } \\
\text { now several behaviour programmes } \\
\text { delivered by the Home Office. In this } \\
\text { article I intend to discuss } \\
\text { psychodrama as a treatment } \\
\text { approach that has been used for the } \\
\text { past } 20 \text { years at H.M.P. Grendon } \\
\text { Underwood and how its application } \\
\text { can change the disruptive internal } \\
\text { worlds of those who offend." ( } p .371 \text { ) }\end{array}$ & Case Study & UK & No & No & No & No \\
\hline $\begin{array}{l}\text { Hamamci, } \\
2006\end{array}$ & Classic & $\begin{array}{l}\text { "...to compare the effects of } \\
\text { cognitive behavioral group therapy } \\
\text { alone with an integration of cognitive } \\
\text { behavioral therapy and psychodrama } \\
\text { in the treatment of individuals with } \\
\text { moderate depression" (p. 201). }\end{array}$ & Quantitative Analysis & Turkey & No & No & No & No \\
\hline Ançel, 2006 & $\begin{array}{l}\text { Role-playing } \\
\text { Empathy }\end{array}$ & $\begin{array}{l}\text { "The purpose of this study was to } \\
\text { determine whether inservice } \\
\text { communication training enhanced } \\
\text { the empathic skills of nurses... The } \\
\text { first training model comprises } \\
\text { specific training programs, such as } \\
\text { skills workshops or psycho- } \\
\text { drama" (p.250). }\end{array}$ & Quantitative Analysis & Turkey & No & No & No & No \\
\hline Blatner, 2007 & $\begin{array}{l}\text { J.L.Moreno } \\
\text { Theory }\end{array}$ & $\begin{array}{l}\text { "In this article, I emphasize that } \\
\text { Moreno's work is more } \\
\text { encompassing than psychodrama, } \\
\text { which was just one of his varied } \\
\text { interests" ( p.160). }\end{array}$ & Theory Discussion & USA & Yes & No & No & No \\
\hline $\begin{array}{l}\text { McVea \& } \\
\text { Reekie, } 2007\end{array}$ & $\begin{array}{l}\text { Role-playing } \\
\text { Spontaneity }\end{array}$ & $\begin{array}{l}\text { "This paper presents the principles of } \\
\text { role-training and illustrates its } \\
\text { application in an individual coaching } \\
\text { context" (p.295). }\end{array}$ & Case Study & Australia & No & No & No & No \\
\hline
\end{tabular}




\begin{tabular}{|c|c|c|c|c|c|c|c|c|}
\hline $\begin{array}{l}\text { Author/s } \\
\text { and } \\
\text { Yoar }\end{array}$ & $\begin{array}{l}\text { PD Approach } \\
\text { or } \\
\text { Tochnique }\end{array}$ & $\begin{array}{c}\text { Research Question } \\
\text { or } \\
\text { Problom Statemont }\end{array}$ & $\begin{array}{c}\text { Research Design } \\
\text { or } \\
\text { Article Typo }\end{array}$ & Country & $\begin{array}{c}\text { Group } \\
\text { Process } \\
\text { Montioned? }\end{array}$ & $\begin{array}{l}\text { Group } \\
\text { Process } \\
\text { Explained? }\end{array}$ & $\begin{array}{l}\text { Group } \\
\text { Process } \\
\text { Examined? }\end{array}$ & $\begin{array}{c}\text { Recommend } \\
\text { Group } \\
\text { Process } \\
\text { Study? }\end{array}$ \\
\hline Somov, 2007 & Classic & $\begin{array}{l}\text {...psychodrama in its classic form... } \\
\text { does not quite fit in with the } \\
\text { outcome-oriented [substance abuse] } \\
\text { rehabilitation culture... } \\
\text { The present article proposes a } \\
\text { psychodrama application that is } \\
\text { specifically designed for the } \\
\text { purposes of substance use relapse } \\
\text { prevention training" ( } p .152 \text { ). }\end{array}$ & Clinical Discussion & USA & Yes & No & No & No \\
\hline $\begin{array}{l}\text { Kipper. } \\
\text { Davelaar, \& } \\
\text { Herst, } 2009\end{array}$ & $\begin{array}{l}\text { Role-playing } \\
\text { Role-reversal } \\
\text { Spontaneity }\end{array}$ & $\begin{array}{l}\text { "The present study addresses the } \\
\text { positive, inh ibiting (controlling) effect } \\
\text { of the executive functions, more as } \\
\text { an integrating force that facilitates } \\
\text { appropriate responses rather then } \\
\text { their relationship to } \\
\text { psychopathology. We predict that } \\
\text { there would be a positive correlation } \\
\text { between a measure of spontaneity } \\
\text { and the ability to ward off } \\
\text { unwarranted interferences as } \\
\text { measured by the Stroop effect." (p. } \\
330 \text { ) }\end{array}$ & Qantitative Analysis & USA & No & No & No & No \\
\hline $\begin{array}{l}\text { Hagedorn \& } \\
\text { Hirshhorn, } \\
2009\end{array}$ & $\begin{array}{l}\text { Role-playing } \\
\text { Surplus Reality }\end{array}$ & $\begin{array}{l}\text { "In a time of cognitive behavioral } \\
\text { approaches and traditional talk } \\
\text { therapy, experiential exercises are } \\
\text { slowly coming into the forefront as an } \\
\text { altemative way to engage clients in } \\
\text { the therapeutic process. Whereas the } \\
\text { authors note the long history behind } \\
\text { the development of experiential } \\
\text { exercises, it is our intent to cover but } \\
\text { a few of the more prominent theories } \\
\text { and techniques to help set the stage } \\
\text { for the exercises we offer herein." (p. } \\
\text { 44) }\end{array}$ & Clinical Discussion & USA & Yes & No & No & No \\
\hline $\begin{array}{l}\text { Dobrescu \& } \\
\text { Lupu, } 2009\end{array}$ & $\begin{array}{l}\text { Classic } \\
\text { Sociometry } \\
\text { Sociogram }\end{array}$ & $\begin{array}{l}\text { "1. Identifying the intervention } \\
\text { possibilities in order to improve } \\
\text { certain psychosocial dimensions that } \\
\text { compete for the enhancement of the } \\
\text { teams' performance capacity. } \\
2 \text { 2. Conceiving and implementing } \\
\text { psychodramas in order to rebalance } \\
\text { the psychosocial relations, reducing } \\
\text { tensions, eliminating conflicts and } \\
\text { emotional reconstruction of the } \\
\text { studied sportive teams. } \\
\text { 3. The study of specific sociometric } \\
\text { dimensions at the sportive } \\
\text { teams." (p. 282) }\end{array}$ & Qualitative Analysis & Romania & No & No & No & No \\
\hline
\end{tabular}


Vol.1. No.2 December, 2013, pp. 105-114

\begin{tabular}{|c|c|c|c|c|c|c|c|c|}
\hline $\begin{array}{l}\text { Author/s } \\
\text { and } \\
\text { Year }\end{array}$ & $\begin{array}{l}\text { PD Approach } \\
\text { or } \\
\text { Tochniquo }\end{array}$ & $\begin{array}{l}\text { Research Question } \\
\text { or } \\
\text { Problem Statement }\end{array}$ & $\begin{array}{c}\text { Research Design } \\
\text { or } \\
\text { Article Typo }\end{array}$ & Country & $\begin{array}{c}\text { Group } \\
\text { Process } \\
\text { Mentioned? }\end{array}$ & $\begin{array}{l}\text { Group } \\
\text { Process } \\
\text { Explained? }\end{array}$ & $\begin{array}{l}\text { Group } \\
\text { Process } \\
\text { Examined? }\end{array}$ & $\begin{array}{l}\text { Recommend } \\
\text { Group } \\
\text { Process } \\
\text { Study? }\end{array}$ \\
\hline $\begin{array}{l}\text { Gatta et al., } \\
2010\end{array}$ & Classic/Analytic & $\begin{array}{l}\text { "The present study aimed to assess } \\
\text { the efficacy of psychodrama as a } \\
\text { therapeutic tool in a group setting } \\
\text { with adolescents suffering from } \\
\text { psychiatric disorders'"(p.241). }\end{array}$ & Quantitative Analysis & Italy & Yes & No & No & Yes \\
\hline Dogan, 2010 & Classic & $\begin{array}{l}\text { “.,the main aim of this study was to } \\
\text { establish the effectiveness of } \\
\text { psychodrama training on young } \\
\text { adults' anxious and avoidant } \\
\text { attachment styles. The secondary } \\
\text { aim of the study was to evaluate the } \\
\text { qualitative gains of psychodrama } \\
\text { training participants" (p.113). }\end{array}$ & Mixed Method & Turkey & No & No & No & No \\
\hline Sparer, 2010 & Classic/Analytic & $\begin{array}{l}\text { "The goal of this paper is to present } \\
\text { the way in which an analyst trained in } \\
\text { the French Model ... approaches the } \\
\text { question of } \\
\text { indication...Psychodrama... which is } \\
\text { useful when the capacity to represent } \\
\text { is limited will be introduced. Two } \\
\text { clinical illustrations of consultations... } \\
\text { will then follow." (p. 1179) }\end{array}$ & Case Study & France & No & No & No & No \\
\hline $\begin{array}{l}\mathrm{Ge}, \mathrm{He}, \& \text { Dai, } \\
2011\end{array}$ & Classic & $\begin{array}{l}\text { "The study uses campus } \\
\text { psychodrama and focuses on } \\
\text { improving college students' } \\
\text { interpersonal trust..." (p.462) }\end{array}$ & Mixed Method & China & Yes & No & No & No \\
\hline $\begin{array}{l}\text { McVea, Gow, } \\
\text { \& Lowe, } 2011\end{array}$ & Classic & $\begin{array}{l}\text { "1. What protagonist processes are } \\
\text { linked to in-session resolution of } \\
\text { painful emotional experience during } \\
\text { psychodrama? } \\
2 \text {. What is the post-session impact of } \\
\text { protagonists' in-session change } \\
\text { processes?" } \\
\text { (p. } 417 \text { ) }\end{array}$ & Mixed Method & Australia & Yes & No & Yes & No \\
\hline Pinel, 2011 & Classic/Analytic & $\begin{array}{l}\text { "...the author proposes an analysis of } \\
\text { the intrapsychic and group process. } \\
\text { He attempts to show that the } \\
\text { outcome of the therapeutic process } \\
\text { relies on a strict transference and } \\
\text { counter-transference } \\
\text { relationship..." (p. 196). }\end{array}$ & Case Study & France & Yes & No & No & No \\
\hline Yaniv, 2011 & Role-playing & $\begin{array}{l}\text { "This overview incorporates current } \\
\text { biological thinking about the } \\
\text { relationship of mind to brain into the } \\
\text { philosophy and techniques of } \\
\text { psychodrama" (p. 52). }\end{array}$ & Literature Revievı & Israel & Yes & No & No & No \\
\hline
\end{tabular}




\begin{tabular}{|c|c|c|c|c|c|c|c|c|}
\hline $\begin{array}{l}\text { Author/s } \\
\text { and } \\
\text { Year }\end{array}$ & $\begin{array}{c}\text { PD Approach } \\
\text { or } \\
\text { Technique }\end{array}$ & $\begin{array}{c}\text { Research Question } \\
\text { or } \\
\text { Problem Statement }\end{array}$ & $\begin{array}{c}\text { Research Design } \\
\text { or } \\
\text { Article Type }\end{array}$ & Country & $\begin{array}{c}\text { Group } \\
\text { Process } \\
\text { Mentioned? }\end{array}$ & $\begin{array}{l}\text { Group } \\
\text { Process } \\
\text { Explained? }\end{array}$ & $\begin{array}{l}\text { Group } \\
\text { Process } \\
\text { Examined? }\end{array}$ & $\begin{array}{c}\text { Recommend } \\
\text { Oroup } \\
\text { Process } \\
\text { Study? }\end{array}$ \\
\hline $\begin{array}{l}\text { Oflaz, Meric, } \\
\text { Yuksel, \& } \\
\text { Ozcan, } 2011\end{array}$ & Classic & $\begin{array}{l}\text { "The purpose of the educational } \\
\text { strategy was to form a group } \\
\text { interaction model to improve the self- } \\
\text { awareness of nurses by means of } \\
\text { psychodrama techniques. It aimed to } \\
\text { help nurses to be aware and to } \\
\text { manage their own emo- tional } \\
\text { reactions towards difficult patients } \\
\text { and situations. This can only be } \\
\text { achieved by dealing explicitly with } \\
\text { uncomfortable, and sometimes } \\
\text { conflicting, feelings that nurses have } \\
\text { to deal with." (p. } 570 \text { ) }\end{array}$ & Qualitative Analysis & Turkey & Yes & No & No & No \\
\hline Carter, 2011 & Classic & $\begin{array}{l}\text { "What are the dramatic sensibilities } \\
\text { and attitudes of a psychodramatist? } \\
\text { What impact do these dramatic } \\
\text { sensibilities have on the } \\
\text { psychodramatist, the protagonist, the } \\
\text { therapeutic relationship, and the } \\
\text { therapeutic process?: (p. 295) }\end{array}$ & Case Study & New Zealand & Yes & No & No & No \\
\hline Yaniv, 2012 & $\begin{array}{c}\text { Role-playing } \\
\text { Role-reversal } \\
\text { Creativity } \\
\text { Empathy } \\
\text { Neurobiology }\end{array}$ & $\begin{array}{l}\text { "...introducing J. L. Moreno's basic } \\
\text { conceptions of roles and role reversal } \\
\text { in psychodrama, followed by a } \\
\text { discussion of how empathy and } \\
\text { creativity may interweave in role } \\
\text { reversal. Finally, I present recent } \\
\text { neuroscientific evidence relating to } \\
\text { these processes..." (p. } 70 \text { ) }\end{array}$ & Literature Review & Israel & Yes & No & No & No \\
\hline
\end{tabular}

PD = Psychodrama; [For definitions of PD Approach or Technique items cf. pp. 2-14]

Gatta et al., (2010), in their study assessing the use of psychodrama groups for the treatment of adolescents with psychiatric disorders, state that a study comparing the therapeutic effectiveness of psychodrama groups with other forms of group psychotherapy is needed in order to gauge the magnitude of the contribution of group process in psychodrama group outcomes.

Although the McVea, Gow, and Lowe (2011) study stated that "The Client Change Interview... [was] adapted for this study to include group impact items" these items were not mentioned in the results or the discussion. Also, in their discussion they state "Group cohesion is widely recognized as a core enabling factor in effective group work... and in this study strong group cohesion in the middle and latter life of the group contributed to the protagonists' readiness" yet no mention is made of how the strength of group cohesion was assessed or measured. They also failed to recommend further studies of the impact of group process in psychodrama groups.

\section{Discussion}

While psychodrama is primarily a form of group psychotherapy, it is found that before the new century, psychodrama practitioners and researchers have largely ignored the group process. In addition, most research findings were not published in peer-review journals. Nevertheless, in the last ten years, most empirical studies of psychodrama have incorporated group process in their analysis or discussion and most of these studies are reported in peer-reviewed journals.

One the other hand, this review has shown that there is still a lack of research studies which examine the interaction of psychodrama and the group process. This is a gap in psychodrama.

It is hoped that the results of this study will stimulate further research in this area. It may also increase awareness among psychodrama trainers, trainees and practitioners of the need to be equally cognizant of both group work and psychodrama processes.

\section{REFERENCES}

Ançel, G. (2006). Developing empathy in nurses: An inservice training programme. Archives of Psychiatric Nursing, 20(6), 249-257.

Bakali, J. V., Wilberg, T., Hagtvet, K. A., \& Lorentzen, S. (2010). Sources accounting for alliance and cohesion at three stages in group psychotherapy: Variance component analyses. Group Dynamics: Theory, Research, and Practice, 14(4), 368-383.

Blatner, A. (2007). Morenean approaches: Recognising psychodrama's many facets. Journal of Group Psychotherapy, Psychodrama and Sociometry, 59(4), 159-170.

Journal of Group Psychotherapy, Psychodrama and Sociometry, 59(4), 159-170. 
Burlingame, G. M., McClendon, D. T., \& Alonso, J. (2011). Cohesion in group therapy. Psychotherapy, 48(1), 34-42.

Carter, P. D. (2011). The dramatic heart of the psychodramatic method. The Arts in Psychotherapy, 38(4), 290-297.

Chang, A., Duck, J., \& Bordia, P. (2006). Understanding the multidimensionality of group development. Small Group Research, 37(4).

Dayton, T. (2005). The Living Stage. Deerfield Beach, Florida: Health Communications Inc.

Dobrescu, T., \& Lupu, G. (2009). Applying the sociodramas and psychodramas with the purpose of improving the psychosocial relations in sports teams. Ovidius University Annals, Series Physical Education and Sport/Science, Movement and Health, 9(2), 281-285.

Dogan, T. (2010). The effects of psychodrama on young adults' attachment styles. The Arts in Psychotherapy, 37, 112-119.

Fullagar, C. J., \& Egleston, D. O. (2008). Norming and performing: Using microworlds to understand the relationship between team cohesiveness and performance. Journal of Applied Social Psychology, 38(10), 2574-2593.

Gatta, M., Lara, D. Z., Lara, D. C., Andrea, S., Paolo, T. C., Giovanni, C., Sorgata, R., Bonafede, C., \& PierAntonio, B. (2010). Analytical psychodrama with adolescents suffering from psycho-behavioral disorder: Short-term effects on psychiatric symptoms. The Arts in Psychotherapy, 37(3), 240-247.

Ge, Y., He, H., \& Dai, L. (2011). Study on group intervention regarding interpersonal trust among college students with campus psychodrama. Health, 3(7), 462-466.

Hagedorn, W. B., \& Hirshhorn, M. A. (2009). When talking won't work: Implementing experiential group activities with addicted clients. The Journal for Specialists in Group Work, 34(1), 43-67.

Hamamci, Z. (2002). The effect of integrating psychodrama and cognitive behavioral therapy on reducing cognitive distortions in interpersonal relationships. Journal of Group Psychotherapy, Psychodrama and Sociometry, 55(1), 3-14.

Hamamci, Z. (2006). Integrating psychodrama and cognitive behavioral therapy to treat moderate depression. The Arts in Psychotherapy, 33(3), 199-207.

Hornsey, M. J., Dwyer, L., \& Tian, P. S. O. (2007). Beyond cohesiveness: Reconceptualizing the link between group processes and outcomes in group psychotherapy. Small Group Research, $38(5), 567-592$.

Jefferies, J. (2005). Psychodrama: Working through action: 'My thank you is for your concern. Group Analysis, 38(3), 371-379.

Kim, K. W. (2003). The effects of being the protagonist in psychodrama. Journal of Group Psychotherapy, Psychodrama and Sociometry, 55(4), 115-127.

Kipper, D. A., \& Hundal, J. (2003). A survey of clinical reports on the application of psychodrama. Journal of Group Psychotherapy, Psychodrama and Sociometry, 55 (4), 141-157.
Kipper, D. A., \& Matumoto, M. (2002). From classical to eclectic psychodrama: Conceptual similarities between psychodrama and psychodynamic and interpersonal group treatments. International Journal of Group Psychotherapy, 52(1), 111-120.

Kipper, D. A., \& Ritchie, T. D. (2003). The effectiveness of psychodramatic techniques: A meta-analysis. Group Dynamics: Theory, Research, and Practice, 7(1), 13-25.

Kipper, D. A., Davelaar, P. S., \& Herst, S. (2009). The relationship between spontaneity and inhibition. The Arts in Psychotherapy, $36(5), 329-334$.

Marmarosh, C., Holtz, A., \& Schottenbauer, M. (2005). Group cohesiveness, group-derived collective self-esteem, group-derived hope, and the well-being of group therapy members. Group Dynamics: Theory, Research, and Practice, 9(1), 32-44.

McVea, C. (2004). It's not enough just to say it works: Research into psychodrama and experiential therapies. ANZPA Journal, 13, $42-46$.

McVea, C., \& Reekie, D. (2007). Freedom to act in new ways: The application of Merino's spontaneity theory and role theory to psychological coaching. Australian Psychologist, 42(4), 295-299.

McVea, C., Gow, K., \& Lowe, R. (2011). Corrective interpersonal experience in psychodrama group therapy: A comprehensive process analysis of significant therapeutic events. Psychotherapy Research, 21(4), 416-429.

Nicholas, M. (2008). Psychodrama in the 21st century: Clinical and educational approaches. International Journal of Group Psychotherapy, 58(3), 425-428.

Nuttman-Shwartz, O., \& Kleinberg, J. (2012). Special issue on international group work and psychotherapy. Clinical Social work Journal,.40, 387-390.

Oflaz, F., Meriç, M., Yuksel, Ç., \& Ozcan, C. T. (2011). Psychodrama: An innovative way of improving self-awareness of nurses. Journal of Psychiatric and Mental Health Nursing, 18(7), 569-575.

Pinel, J. P. (2011). Group analytical work with violent preadolescents: working through and subjectivation. Group Analysis, 44(2), 196-207.

Somov, P. G. (2007). A psychodrama group for substance use relapse prevention training. The Arts in Psychotherapy, 35(2), 151-161.

Sparer, E. A. (2010). The French model at work: Indication and the Jean Favreau Centre for Consultation. International Journal of Psychoanalysis, 91(5), 1179-1199.

Treadwell, T. W., \& Kumar, V. K. (2002). Introduction to the special issue on cognitive behavioural therapy and psychodrama. Journal of Group Psychotherapy, Psychodrama and Sociometry, $55(2 / 3), 51-53$.

Yaniv, D. (2011). Revisiting Morenian psychodramatic encounter in light of contemporary neuroscience: Relationship between empathy and creativity. The Arts in Psychotherapy, 38(1), 52-58.

Yaniv, D. (2012). Dynamics of creativity and empathy in role 
reversal: Contributions from neuroscience. Review of General Psychology, 16(1), 70-77. 